\title{
Japan
}

\section{Learning from Japanese legal tradition}

\section{by Professor Yutaka Tajima}

$\mathrm{J}$ apanese law is an amalgam of a number of different traditions and is an interesting source of study for Europeans at a time when the traditional concept of the nation state is breaking down.

\section{JAPANESE LEGAL HISTORY}

Prince Shotoku's Code of 17 articles, promulgated in 604 and described by some as the first Japanese Constitution, embodied a mixture of Buddhist and Confucianist values. It also represented a kind of social contract in so far as it set out the relationships and mutual obligations that should exist between the different members of the state, from the lowest to the highest. At the heart of this code was the spirit of 'harmony' and, despite many subsequent elaborations and reformulations, this has remained the dominant principle throughout the legal history of Japan, of which the code can be seen as the foundation.

The period of the Tokugawa Shogunate (1680-1868) requires special attention, because it was the time when the influence of Confucianism became conspicuous. The period between 604 and 1600 was a feudal time, when many provincial lords governed their own provinces; after this chaotic period, the nation reached a prolonged state of political equilibrium, economic prosperity and social calm. In contrast with such ancient emperor's ordinances as Taiho Ritsuryo in 701 and Yoro Ritsuro in 718, which were oriented towards Chinese law, the laws created during the Tokugawa era contained characteristics unique to Japanese culture. It is true that the study of Confucian prinicples was popular and prevailing at that time, but such principles were interpreted in a distinctive, Japanese way. Apart from the code system, a large amount of customary law in Japan was created during the period under the influence of Confucianism.

Modernisation is considered to have begun in Japan in 1868. Its long period of international isolation was broken in 1853 by the American Commodore Perry, who threatened the Shogunate Government and forced it to open up the country. After that, foreign influences on Japanese law became noticeable and, indeed, substantial and numerous. In the Meiji era (1868-1911, Japanese law was modernised using principles derived from European legal systems, predominantly those of Germany, France and Britain. After the end of World War II, American law came to exert a direct and marked influence on the Japanese legal system as a consequence of the American occupation.

The Japanese legal system today is therefore a hybrid, but its core is still unmistakably composed of Japanese traditions and beliefs - as can be seen by the way in which various foreign principles have been modified and filtered into the Japanese system. While taking full account of these influences and looking at divergent developments in foreign legal systems, this article sets out to illuminate this hybrid by examining the philosophies and reasoning underpinning the Japanese legal system, considered within the context of Japanese culture.

When Japan opened up the country, the Ministry of Education immediately sent 100 young students to study abroad. One of the exam questions for their selection was 'Explain Entick $v$ Carrington (1765) 19 St Tr 1030' and another, a year later, was 'State the rule of Smith v Buchan (1888) 58 LT 710'. These questions show that the examiner, unknown to us, was at least aware of the leading English cases, and in fact, those who were selected by the examination went to London. Their first mission was to devise a model constitution. The first modern Constitution of Japan passed through the Diet on 11 February 1889 and was promulgated on 29 November 1890. For some reason it was said that the constitution was German-oriented, despite being much influenced by Dicey and by the constitutions of kingdoms such as Denmark, Norway and Holland. The federal constitution of the German Republic of the time did not resemble the said constitution.

\section{WRITTEN CONSTITUTION}

Today, at the top of the Japanese legal hierarchy lies a written constitution, composed of 103 articles, which was promulgated on 3 November 1946. Looking at the present constitution from the point of view of its function in defining the framework of government, the fundamental provisions are contained mainly in art. 41, 65 and 76, namely:

'the Diet shall be the highest organ of the state power, and shall be the sole law-making organ of the State' (art. 41)

'the executive power shall be vested in the Cabinet' (art. 65)

'[all] judicial power is vested in a Supreme Court and in such inferior courts as are established by law'. (art. 76)

Taken together, these constitutional provisions create a governmental structure based on the Western concept of separation of powers.

Chapter 1 of the constitution is composed of eight articles and provides for the existence and the role of the Emperor. Under the present constitution, the Emperor has a symbolic role similar to that of the Queen in the United Kingdom. Inclusion of these provisions was 
designed to preserve the historical continuity that Japan had enjoyèd since at least the time of Prince Shotoku's Code in 604.

Chapter 2, which contains a single provision in the form of art. 9 , is perhaps more important, It states that:

'the Japanese people renounce war as a sovereign right of the nation and the threat or use of force as means of settling international disputes.'

The interpretation of this particular article has been most controversial, since leading constitutional law professors have interpreted the provision as an absolute ban on all use of force and threat of force, including that in self-defence. In recent years, however, constitutional lawyers have recognised the existence of international peacekeeping and other obligations under the United Nations Charter.

In addition to those mentioned above, there are chapters on the Bill of Rights (Chapter 3) and on Local Government (Chapter8). These provisions were derived from the American Constitution, but in fact most also resemble those in the UK Bill of Rights and the Act of Succession. As a whole, the application of the American constitutional principles has been distorted, as exemplified by the celebrated Defence Force funeral case (Nakaya v State, Sup Ct and Bench Decision, Showa 63 [1988] June 1, Minshu vol. 42, no. 5, p. 277). In this case, the wife of a trainee soldier in the Air Force brought an action against the defence force over the funeral arrangements in relation to her late husband, who was killed in a training accident along with a number of other trainees. The funeral was proposed to proceed in accordance with Shinto practice, but the dead husband and his wife were very devout Christians. The Supreme Court held that freedom of religion provides for the principle of 'toleration', and interpreted this as meaning that the wife should accept the Shinto funeral (or not attend). The court considered that harmony in the defence force was more important than the individual's right to the free exercise of religion.

\section{ROPPO}

Roppo (six codes) contains the fundamental laws of the country: the Civil Code, Commercial Code, Code of Civil Procedure, Criminal Code and Code of Criminal Procedure, in addition to the Constitutional Code explained above. The Meiji Government hastened the promulgation of these codes, because they felt that it was essential to enhance the Japan's international political status in the so that Japan could revise the unequal treaty ratified by Tairo li. The influence of French, German and English law is very clear.

The Diet usually produces about 150 statutes every year in connection with relevant provisions of the basic codes. Some are comprehensive, but normally they are piecemeal. I have published four papers in England explaining recent legislation on banking, tracing assets, and shareholders' suits in Japan, and these exemplify such statutes. In this article I would like to take a more basic example - the 'exemption clause' in contract.

\section{Exemption clause in contracts}

There is a provision in the standard contract form for warehousing which states that the warehousing company shall not be liable for the loss of deposited property unless the depositor can prove gross negligence on the part of the said company. In the United Kingdom, this kind of exemption clause'would be tested in the courts on the bases of reasonableness. The Unfair Contract Terms Act 1977, for example, states that:

'a person cannot exclude or restrict liability except in so far as the contract term satisfies the requirement of reasonableness'.

British lawyers would be reminded of the George Mitchell case (George Mitchell (Chesterhall) Ltd v Finney Lock Seeds Ltd [1983] 2 All ER 737; 1 All ER 108), or the recent case of Dampskibsselskabet af 1912 and Anor v Motis Exports Ltd (CA, 21 December 1999). In the United States, the test is based around the principle of 'unconscionability' or it may be a matter of 'fairness', to be determined by the Federal Trade Commission.

In Japan, the end result of actual cases may be the same, but such a clause would not be tested by the court. If a case arose to test such a clause, the company would know that it would be invalidated by the court, and therefore they would not use the clause. This means that such a contractual clause is effectively only a means to discourage depositors from suing the company, and indeed a written contract is a starting point for settlement of disputes. In this connection, it might be recalled that the abovementioned six codes were drafted in a very short period, and the reader may correctly guess that the mentality that produced them might have been the same as in the case of the standard contract form. Japanese society is much more strongly based on the traditional customary law than on codes and statutes.

Before I explain the customary law, let me quckly add another example of a tort law. As a premise, it should be noted that s. 309 of the Civil Code provides that:

'a person who violates intentionally or negligently the right of another is bound to make compensation for damage arising therefrom'.

Professor Hoshino states that influence of French law is obvious. Here, differences exist between English law and continental law. The English approach to the subject bears the stamp of the kinds of action which existed in former times: specific torts were sanctioned in a variety of actions, imparting rules which were different in each procedural form. In French law, no specific torts are to be found, but there is a general principle similar to the Japanese Civil Code, s. 709. Article 1382 of the French Code states that: 
'any act whatever of man, which causes damage to another, obliges the person by whose fault it occurred to make good that damage.'

Incidentally, a wrongful act can be viewed as a breach of implied contract not to injure a good neighbour, and therefore, the provision for 'damages' (s. 416), which is English law, is applicable both to contracts and to torts.

In Doe (an infant) v Roe (a neighbour), the Tsu District Court decision of 21 April of Showa 58 [1983], Hanrei Jiho no. 1083 , p. 135 , the parents of a child brought a lawsuit against their neighbour on the ground of negligence. (Incidentally, the city was also the co-defendant, but the court discharged the issue on the ground of no standing.) The child was drowned in a river during a hike organised as part of the citizens' recreational activity of Yokkaichi City. The defendant was the leader of the picnic. The child was playing with the defendant's family, but the defendant failed to pay due care to the child. When this lawsuit was publicised, many people who had no relation to the parties, telephoned to ask them to stop the litigation. In the view of the public in general, the parties should not destroy the harmony of the local community by such litigation. In their view, this should be a matter for a private settlement under which the neighbour should console the parents and the parents in turn should tolerate the unintended negligence.

\section{CUSTOMARY LAW}

The final part of this article looks at customary law. The spirit of 'harmony' is the lifeblood of Japanese law, and the statutory laws are, as it were, its physical appearance. When the six codes were enacted, the drafters carefully added several general provisions. For instance, statutory provisions for 'public policy' (s. 90, Civil Code), 'good morals', 'fidelity and good faith' and the like, can be good grounds for the court to finesse the normally expected conclusions. In 1875, art. 3 of the Great Council's Proclamation No. 103 expressed its desire to preserve customary law as follows:

'In civil trials, those matters for which there is no written law are governed by custom, and those matters for which there is no custom shall be adjudicated by reason (jori).'

One example of jori can be seen in the Unazuki Onsen case (Y ${ }_{v}$ Kurobe Railway Co, Taihan Showa 10, October 5, Minshu vol. 14 , no. 22, p. 1965).

The Japanese people are fond of hot springs, as the Romans were. The Unazuki Onsen is one of Japan's most famous hot spring resorts. Hot springs are normally concerned with the right to 'common', which is a sort of customary law provided for in s. 263. This section states that the matter of common shall be settled in accordance with customary law. Here, the Kurobe Railway Company had the right to common, and created a very long pipeline to carry hot water from the spring source in the mountain to the village resort where there were traditional inns. A villager who owned a precipitous cliff became aware of the fact that the pipeline touched his land. He sought the remedy of ejectment on the basis of his ownership. This was of course an attempt to obtain an excessive amount of compensation The court held that this lawsuit was an abuse of right in the light of jori, because no damage was caused to the plaintiff.

Jori is much concerned with a public opinion and is also related to 'discretion'. Section 248 of the Criminal Code Procedure provides that 'character, age and circumstance' of the suspect may be taken into consideration in determining not to prosecute. The discretion to prosecute is also dependent on the jori. 'Discretion', on the other hand, is much more concerned with administration. Perhaps gyosei shido (administrative guidance) is better known than prosecutorial discretion.

In England, judicial review has been an important issue for administrative law reform. Discretion was a controversial matter. In contrast, discretion, at least until the recent past, was much favoured by Japanese lawyers. For example, when the Antitrust Act was enacted in 1947, the principles of the Act were unfamiliar to most Japanese lawyers. It could be said that this was imposed by the American occupation authority shortly after World War II. Many provisions of the statute were mere translations of American antitrust laws. As a consequence, the lawyers began telephoning the FTC officials for guidance - a practice that became known as gyosei shido (administrative guidance). Unfortunately, however, 'discretion' was often abused and became notorious as a bad law, particularly among foreign lawyers. Generally speaking, however, it functioned properly.

\section{CONCLUSION}

I would like to add an important note. This article refers to the laws of 10 countries, but an eminent professor of law has pointed out that more than 40 countries in total have influenced the present Japanese legal system. This supports my principal thesis that Japanese legal tradition respects 'the spirit of harmony', not only in the domestic field but also in the international domain. In this age of globalisation, the Japanese people aspire to co-operate with peace-loving nations of the world and, in order to create a new international law system, they seek harmony among nations.

\section{Professor Yutaka Tajima}

University of Tsukuba, Japan

This article is based on a lecture given to the British-Japanese Law Association in association with the Society for Advanced Legal Studies. 